\title{
DESAIN PEMBELAJARAN TARI DENGAN PENDEKATAN PAIKEM GEMBROT DALAM THEORY OF ART DI SEKOLAH DASAR
}

\author{
Arina Restian \\ Program Studi Pendidikan Guru Sekolah dasar, Fakultas Keguruan dan Ilmu Pendidikan, \\ Universitas Muhammadiyah Malang \\ e-mail: arina.poenya@gmail.com
}

\begin{abstract}
Dance teacher have a very important role in improving the learning outcomes of students in schools in learning the art of dance with management in the classroom. The field of dance lessons more emphasis on aspects of psychomotor, and this is what distinguishes the field of dance lesson with other lessons. So the solution was also different. One form solution is to select or determine the learning approaches that enable learners to participate actively in the learning and learning goals can be achieved. One approach appropriate learning is active learning, creative, effective, and fun (PAKEM) which requires the activity of teachers and students in the learning process. PAKEM make students can be more creative and learning process can take place in an effective and enjoyable. This study aims to determine learning the art of dance at the junior high schools in Malang by using. Dance lesson with an art management approaches. The scope of the study include: (1) Dance Lessons Planning, (2) Implementation of learning the art of dance (3) The role of teachers and students in learning the art of dance, (4) The results of student learning. The results showed that the dance teacher has made the completeness or learning devices, one of which is learning implementation plan (RPP). When viewed from the implementation of the lesson plan in mind that the learning is in conformity with the characteristics of PAKEM namely making students active and creative in finding new ideas. In addition teachers are also active in managing the classroom so as to create effective learning in a pleasant atmosphere. Additionally supporting infrastructure PAKEM learning approach is sufficient in the implementation of learning the art of dance, especially in the optimal use of instructional media so as to support the teaching and learning process (PBM). The results of the second study found that learning the art of dance in Junior High School in Malang in addition to using PAKEM approach also uses the approach to CTL (Contexstual Teaching and Learning) in with the intent to be able to achieve the learning objectives and lesson plans that have been made previously. So as to create a more conducive learning environment in achieving optimal learning outcomes.
\end{abstract}

Abstrak: Guru seni tari memiliki peranan yang sangat penting dalam meningkatkan hasil belajar peserta didik di sekolah dalam pembelajaran seni tari dengan menajemen di kelas. Pelajaran bidang seni tari lebih banyak menekankan pada aspek psikomotorik dan hal ini yang membedakan pelajaran bidang seni tari dengan pelajaran lainya. Sehingga penanganannya pun juga berbeda. Salah satu bentuk penanganannya adalah dengan cara memilih atau menentukan pendekatan pembelajaran yang memungkinkan peserta didik berpartisipasi secara aktif dalam pembelajaran dan tujuan pembelajaran bisa tercapai. Salah satu pendekatan pembelajaran yang tepat adalah pembelajaran aktif, kreatif, efektif, dan menyenangkan (PAKEM) yang menuntut keaktifan guru beserta siswa dalam proses pembelajaran. Dengan PAKEM siswa bisa lebih kreatif dan proses belajar mengajar dapat berlangsung secara efektif dan menyenangkan. Penelitian ini bertujuan untuk mengetahui pembelajaran seni tari pada SD di Malang dengan menggunakan pembelajaran seni tari dengan pendekatan menajemen seni. Ruang lingkup penelitian ini meliputi: (1) Perencanaan Pembelajaran Seni Tari, (2) Pelaksanaan pembelajaran seni tari (3) Peran serta guru siswa dalam pembelajaran seni tari, (4) Hasil belajar siswa. Hasil penelitian menunjukkan bahwa guru seni tari telah membuat kelengkapan atau perangkat pembelajaran, salah satunya adalah rencana pelaksanaan pembelajaran (RPP). Bila dilihat dari rencana pelaksanaan pembelajaran diketahui bahwa dalam pembelajaran sudah sesuai dengan karakteristik PAKEM yaitu membuat siswa aktif dan kreatif dalam menemukan ide baru. 


\begin{abstract}
Selain itu guru juga aktif dalam mengelola kelas sehingga tercipta pembelajaran yang efektif dalam suasana yang menyenangkan. Selain itu sarana prasarana pendukung pembelajaran dengan pendekatan PAKEM sudah cukup dalam pelaksanaan pembelajaran seni tari khususnya dalam penggunaan media pembelajaran yang optimal sehingga mampu mendukung proses belajar mengajar (PBM). Hasil penelitian kedua ditemukan bahwa pembelajaran seni tari pada di SD Negeri Malang selain menggunakan pendekatan PAKEM juga menggunakan pendekatan CTL (Contexstual Teaching and Learning) secara beriringan dengan maksud agar mampu mencapai tujuan pembelajaran serta rencana pembelajaran yang telah dibuat sebelumnya. Sehingga tercipta lingkungan belajar yang lebih kondusif dalam pencapaian hasil belajar secara optimal.
\end{abstract}

Kata Kunci: Desain pembelajaran PAIKEM GEMBROT, seni tari

\section{PENDAHULUAN}

Proses belajar mengajar guru harus memiliki strategi, agar siswa dapat belajar secara efektif dan efisien, mengena pada tutujuan yang diharapkan. Dan untuk memiliki strategi itu ialah harus menguasai teknik-teknik penyajian atau biasannya disebut dengan metode pengajaran. Hal ini diharapkan agar bisa mengoptimalkan hasil belajar siswa dalam penyerapan materi yang telah disampaikan, selain itu juga dapat meningkatkan mutu dan ketrampilan siswa yang diperlukan dengan tujuan utamanya untuk tercapainya proses pembelajaran.

Berbagai definisi pengembangan pem belajaran dikemukakan oleh para pakar pendidikan. Menurut Suparman (1997: 2-3) menuturkan bahwa: pengembangan pembelajaran adalah proses yang sistematik dalam mengidentifikasi masalah, mengembangkan bahwa bahan ajar dan strategi pembelajaran, serta bagaimana mengevaluasi efektifitas dan efisiensinya dalam mencapai tujuan pembelajaran. Jadi pengembangan pembelajaran merupakan suatu proses yang sistematis.

Pembelajaran yang efektif dan efisien sangat penting dalam terciptanya tujuan pembelajaran, lingkungan yang kondusif akan berpengaruh besar untuk keberlangsungan pembelajaran. Adapun strategi pembelajaran yang efektif dan efisien adalah (1) Adanya komunikasi yang jelas antara guru sebagai pengajar dan murid sebagai pelajar;
(2) Adanya partisipasi dari peserta didik; (3) Media pembelajaran yang digunakan dapat merangsang peserta didik; (4) Relevan dengan isi/materi pembelajaran; (5) Metode dan tekhnik yang digunakan difokuskan pada tujuan yang ingin dicapai.

Undang-undang RI Nomor 20 Tahun 2003 (UU 20/2003) tentang Sistem Pendidikan Nasional dan Peraturan Pemerintah RI Nomor 19 Tahun 2005 (PP 19/2005) ten tang Standar Nasional Pendidikan mengamanatkan kurikulum pada KTSP jenjang pendidikan dasar dan menengah disusun oleh satuan pendidikan yang mengacu pada SI dan SKL serta berpedoman pada panduan yang disusun oleh Badan Standar Nasional Pendidikan (BSNP).

Proses pembelajaran 2004 pada mata pelajaran kesenian, khususnya pada bidang seni tari di berbagai sekolah sering kali di jumpai kesan kurang terstruktur karena tidak adanya acuan serta pola pembelajaran yang dapat menarik siswa untuk lebih kreatif dalam mengikuti proses pembelajaran. Selain itu, bila dikaitkan dengan kurikulum 2004 maka setiap guru di sekolah hanya mengikuti dan melaksanakan kurikulum yang telah dibuat oleh Tim Pusat. Dengan demikian, guru kurang menyadari tentang variasi pembelajaran sehingga pembelajaran kurang efektif. Kondisi inilah yang digunakan sebagai pedoman untuk melakukan penelitian ini. Penelitian pada proses pembelajaran pernah diteliti oleh Widya Heri Setyawati tahun 2000 yang berjudul Studi 
Proses Pembelajaran Sekolah Alkitab di Sekolah Alkitab Batu, bahwa proses pembelajaran harus di dukung oleh tenaga pengajar dan pemilihan strategi pembelajaran yang tepat sehingga tercapai tujuan pembelajaran, begitu juga pada pembelajaran seni tari. Maka dari itu pada pembelajaran seni tari juga harus memiliki strategi pembelajaran yang mendukung, apalagi pelajaran seni tari lebih menekankan pada aspek psikomotorik siswa yaitu perbuatan siswa sehingga dengan adanya suatu strategi ini bisa lebih terarah dan terfokus.

Dengan adanya KTSP ini nampaknya memberi peluang bagi sekolah, guru, dan peserta didik untuk mengembangkan sesuai dengan kondisi lingkungan, baik lingkungan sosial maupun kondisi sekolah dan juga peserta didiknya. Sehingga pembelajaran lebih optimal karena telah disesuaikan dengan kondisi tertentu dan akan banyak bermunculan kekreatifan dalam pembelajaran baik dari segi pendidik maupun peserta didik. Dengan adanya kondisi kurikulum KTSP tersebut tentunya tiap sekolah memiliki gaya pelaksanaan dan pendekatan yang berbeda-beda, begitu juga dengan penerapan pembelajaran seni tari di SD Malang.

Dengan adanya kurikulum KTSP, pelaksanaan pembelajaran mata pelajaran seni budaya khususnya seni tari di SD Malang menggunakan pendekatan PAKEM. Pakem yang merupakan singkatan dari Pembelajaran Aktif, Kreatif, Efektif dan Menyenangkan, merupakan sebuah model pembelajaran kontekstual yang melibatkan paling sedikit empat prinsip utama dalam proses pembelajarannya. Pertama, proses interaksi (siswa berinteraksi secara aktif dengan guru, rekan siswa, multimedia, referensi, lingkungan dsb). Kedua, proses komunikasi (siswa mengkomunikasikan pengalaman belajar mereka dengan guru dan rekan siswa lain melalui cerita, atau dialog). Ketiga, proses refleksi, (siswa memikirkan kembali tentang kebermaknaan apa yang mereka telah pelajari, dan apa yang mereka telah la- kukan). Keempat, proses eksplorasi (siswa mengalami langsung dengan melibatkan semua indera mereka melalui pengamatan, percobaan, penyelidikan dan/atau wawancara).

Hal tersebut selaras dengan yang diungkapkan oleh Taslimuharom (2007) pada program Workstation P4TK-BMTII Bandung tahun 2007 yang menyatakan bahwa "PAKEM"adalah Pembelajaran Aktif, Kreatif, Efektif dan Menyenangkan. Disamping metodologi pembelajaran dengan nama atau sebutan"PAKEM", muncul pula nama yang dikeluarkan di daerah Jawa Tengah dengan sebutan "PAIKEM GEMBROT (Pembelajaran Aktif, Inovatif, Kreatif, Efektif, Menyenangkan, Gembira dan Berbobot)".

Keikutsertaan seni tari menjadi bagian mata pelajaran Pendidikan Seni Budaya merupakan salah satu usaha sekolah untuk mengembangkan kemampuan siswa untuk berapresiasi dan berkarya kreatif melalui seni tari. Selain wawasan, nilai-nilai pendidikan seni tari secara dangkal dapat ditemukan pada gerak-gerak lembut-kasar, aturanaturan tertentu, sikap gerak yang ada di dalamnya dan sebagainya, yang kesemuanya itu dapat dipakai untuk menanamkan sikap percaya diri, disiplin, dan keteguhan jiwa seseorang (siswa).

Adapun alasan-alasan lain dalam melakukan penelitian ini adalah SMPN $20 \mathrm{Ma}-$ lang adalah sekolah menengah pertama yang sudah membuat kelengkapan perangkat pembelajaran yang baik dan lengkap seperti rencana pembelajaran dan Silabus. Selain itu SD di Malang telah memasukkan seni tari sebagai mata pelajaran intrakurikuler bagi siswa. Serta di SD di Malang ini menggunakan pendekatan PAKEM dalam pembelajaran seni tari. Hal inilah yang menggugah peneniliti untuk mengetahui secara mendalam bagaimana penerapan pendekatan manajemen seni dengan pendekatan paikem Gembrot PAKEM SD di Malang dalam pembelajaran seni tari. 
Berdasarkan permasalahan yang timbul maka dirasa perlu diadakan penelitian tentang proses pembelajaran seni tari, dalam penelitian ini penulis mengambil judul "Pendekatan PAKEM Dalam Pembelajaran Seni Tari Pada SD di Malang".

Berdasarkan hasil penelitian di atas, paparan berikut akan menyajikan pembahasan dari hasil data penelitian berupa pendekatan manajemen seni sebagai Berikut: (1) perencanaan pendekatan PAKEM dalam pembelajaran seni tari, (2) pelaksanaan penerapan pendekatan PAKEM dalam pembelajaran seni tari, (3) peran serta guru dan siswa dalam pembelajaran seni tari dengan menggunakan pendekatan PAKEM, (4) produk hasil belajar yang dihasilkan dalam pembelajaran seni tari dengan menggunakan pendekatan PAKEM. Berikut penjabaran hasil dari penelitian dengan teori-teori yang digunakan:

\section{A. Perencanaan pembelajaran seni tari pada SD di Malang}

Sesuai dengan tahapan perencanaan pembelajaran, guru sebagai informator harus memiliki keahlian dalam bidangnya karena ini merupakan modal dasar bagi guru agar pembelajaran dapat terlaksana dan tercapai dengan baik. Sikap profesionalisme seorang guru dalam tahapan persiapan ini dibutuhkan baik dalam merancang program pembelajaran maupun dalam bidang penguasaan materi di bidangnya. Tahap perencanaan/persiapan ini harus diperhatikan pula bagaimana penyusunan rancangan kegiatan belajar mengajar, baik itu yang berkaitan dengan tujuan, metode, media, sumber, evaluasi, dan kegiatan belajar siswa itu sendiri (Asep Hery Dermawan, dkk 2007: 9.9)

Berdasarkan hasil penelitian adalah bahwa guru dalam perencanan pembelajaran telah membuat kelengkapan-kelengkapan perangkat pembelajaran yang telah disesuaikan dengan kurikulum seperti Program Tahunan (Prota), Program Semesrter
(Promes), Silabus, dan Rencana Pelaksanaan Pembelajaran (RPP). Kesemuanya itu merupakan patokan atau standar kompetensi yang harus dicapai dalam pembelajaran.

Hal tersebut harus dilakukan oleh guru seni tari sebelum memulai proses pembelajaran serta semua yang diperlukan harus terkonsep dengan jelas agar guru dapat mengacu pada tujuan pembelajaran yang hendak dicapai. Pada hasil penelitian yang didapat bahwa Program Tahunan (Prota), Program Semester (Promes), Silabus dan RPP yang telah dibuat oleh guru seni tari SMPN 20 Malang memiliki dua standar kompetensi yang harus dicapai dalam pelaksanaan pembelajaran antara lain : "Mengapresiasi Karya Seni Tari dan Mengekspresikan Diri Melalui Karya Seni Tari”. Kedua standar kompetensi ini harus mampu dilaksanakan dan dicapai guru. Disini peneliti akan memaparkan secara rinci tentang perencanaan pembelajaran yang telah dibuat oleh guru seni tari. Adapun penjelasan dari perangkat pembelajaran seperti Prota, Promes, silabus, dan Rencana Pelaksanaan Pembelajaran (RPP) adalah sebagai berikut:

\section{Program Tahunan (Prota)}

Dari hasil dokumentasi yang diperoleh bahwa program tahunan (Prota) yang telah dibuat oleh guru seni tari bila dikaitkan dengan hasil observasi di lapangan adalah bahwa prota sudah dibuat dan dilaksanakan oleh guru seni tari. Hal ini terlihat bahwa setiap pembelajaran seni tari guru selalu melihat prota sebagai acuan dalam pemberian materi sehingga materi yang diberikan ini sesuai dengan kompetensi dasar serta guru juga sangat memperhatikan alokasi waktu yang telah dibuat sebelumnya.

Dengan demikian pembelajaran tidak akan melenceng dari apa yang telah direncanakan oleh guru seni tari dalam program tahunan (Prota) dan berjalan secara terstruktur. Dan sesuai dengan pendekatan PAKEM dari pemaparan diatas bahwa pro- 
gram tahunan (Prota) telah dibuat oleh guru dan dijadikan sebagai pedoman untuk program-program lainya. Di sini peneliti mencantumkan progaram tahunan pada pelajaran seni tari pada SMPN di Malang pada daftar lampiran.

\section{Program Semester (Promes)}

Berdasarkan hasil dokumentasi yang telah dilakukan, bahwa program semester untuk pelajaran seni tari pada semester ganjil pada SD di Malang tahun pelajaran 2011/2012 telah dibuat oleh guru seni tari. Disini peneliti melihat bahwa format dalam program semester yang telah dibuat terdiri dari kolom-kolom yang isinya adalah kolom standar kompetensi yang ingin dicapai dalam satu semester serta kolom pelaksanaan yang merupakan perencanaan waktu untuk melaksanakan pembelajaran sesuai dengan standar kompetensi yang ditentukan sebelumnya dalam bentuk bulan yang di dalamnya terdapat kolom per minggu.

Program semester ini merupakan penjabaran secara rinci dari program tahunan (Prota) yang berisikan tentang garis-garis besar mengenai hal yang akan dilaksanakan dan dicapai dalam satu semester. Dalam pelaksanaanya berdasarkan dokumentasi guru telah membuat pelaksanaan pembelajaran seni tari dimulai dari bulan Juli sampai dengan bulan Januari yang masingmasing bulannya harus mencapai standar kompetensi yang telah dibuat sebelumnya. Misalnya guru dalam memberikan materi melihat standar kompetensi yang ingin dicapai dalam minggu itu, guru menandai kolom pelaksanaan dengan centang atau blok warna bila sudah terlaksana sehingga guru mengetahui standar kompetensi yang sudah dilaksanakan atau belum dengan melihat kolom pelaksanaan.

\section{a). Materi Apresiasi}

Di dalam Standar Kompetensi "Mengapresiasi Karya Seni Tari” memiliki dua kompetensi dasar yaitu: 1) mengidentifikasi karya seni tari nusantara dan mancanegara. 2) menampilkan sikap apresiatif terhadap keunikan tari nusantara dan mancanegara. Kompetensi Dasar pertama memiliki dua sub Kompetensi Dasar yaitu: a) menentukan daerah dan negara asal tari nusantara dan mancanegara. b) mengidentifikasikan ciri-ciri tari nusantara dan mancanegara. Pada sub kompetensi dasar pertama disini guru dalam pembelajaran seni tari memberikan penjelasan materi tentang tari nusantara dan mancanegara, adapun materi tari mancanegara guru mengambil contoh Tari Balet, Tari Tanggo, Tari Balroom/Salsa (tari berpasangan mancanegara). Sedangkan untuk materi tari nusantara guru mengambil contoh tari dari daerah Bali, Jawa Timur, Madura, Jawa Tengah, Aceh, dan sebagainya. Kemudian setelah guru selesai menyampaikan materi, siswa disuruh untuk mencari tari-tarian lain yang berasal dari mancanegara atau nusantara dan mendiskusikan secara berkelompok yang nanti hasilnya akan dipresentasikan di kelas.

Pada sub kompetensi dasar kedua disini guru menugasi siswa untuk mendeskripsikan ciri-ciri tari nusantara dan mancanegara secara kelompok sebagai tugas lanjutan dari sub kompetensi dasar pertama. Dan hasilnya siswa mampu menyebutkan macam-macam tari-tari yang ada di nusantara dan mancanegara beserta ciri-cirinya, sehingga untuk standar kompetensi mengidentifikasi karya seni tari nusantara dan mancanegara sudah terlaksana.

Sedangkan untuk Kompetensi Dasar kedua memiliki tujuh sub Kompetensi Dasar yaitu: a) menjelaskan menjelaskan ciri khas bentuk iringan tari, b) Mengamati tata rias dan busana tari, c) mengamati properti tari, d) mengamati gerak tari nusantara, e) menyebutkan fungsi penyajian tari, f) menyebutkan nama tokoh dan karyanya, g) Menyebutkan nama dan daerah asal alat musik. Dari berbagai kompetensi dasar yang disebutkan diatas, guru dalam pembelajarannya menayangkan video sebuah tarian kemudian guru memberikan lembar hasil kerja yang isinya adalah poin-poin yang di- 
sebutkan diatas untuk dikerjakan secara berkelompok, sehingga siswa bisa terarah dalam mengerjakan tugas dan mencapai perolehan yang telah direncanakan.

b). Materi Ekspresi

Sedangkan untuk materi "Mengekspresikan Diri Melalui Karya Seni Tari" memiliki dua standar kompetensi yaitu: 1) mengeksplorasi gerak tari nusantara dan mancanegara. 2) mengekplorasi pola lantai dalam tari kelompok. Kompetensi Dasar pertama memiliki lima sub Kompetensi Dasar yaitu: a) mengamati gerak tari, b) menentukan ide tari, c) melakukan pencarian gerak, d) mengembangkan gerak tari, e) Melaksanakan latihan tari sesuai dengan musik iringan. Sedangkan untuk Kompetensi Dasar kedua memiliki dua sub Kompetensi Dasar yaitu: a) Menyusun pola lantai kelompok, b) Memperagakan tari secara berkelompok. Pada sub kompetensi dasar pertama yaitu mengamati gerak tari disini guru memberikan contoh gerakan tari berdasarkan tema kepada siswa agar siswa terinspirasi melakukan gerakan-gerakan lain. Pada sub kompetensi kedua yaitu menentukan ide, lanjutan dari poin pertama setelah siswa melihat contoh yang diberikan guru diharapkan siswa mampu melakukan penggalian ide baru secara berkelompok untuk membuat gerakan berdasarkan ide yang mereka tentukan. Selain itu pada poin ketiga bila siswa telah menemukan ide yang telah mereka tentukan, maka mereka harus mampu merancang gerakan dan mengembangkanya sehingga variasi gerak bisa lebih banyak. Kemudian agar gerak yang telah disusun terlihat bagus maka siswa harus menyempurnakan dengan iringan yang sesuai sehingga mendukung gerakan tari yang telah mereka buat. 2) yaitu menyusun pola lantai kelompok, disini setelah siswa menentukan iringan yang dipakai sebagai pendukung gerakan yang sudah dibuat, maka siswa secara berkelompok harus menyusun pola lantai agar dalam memperagakan tari- an tersebut bisa terlihat bagus dan tidak monoton atau tidak menjenuhkan.

Pada penyusunan program semester (Promes) SD di Malang, guru telah membuatnya berdasarkan penjabaran dari program tahunan (Prota) yang sebelumnya telah dibuat. Selain itu dalam menggunakan program semester ini bu Umi (bukan nama sebenarnya) selalu melihat pokok bahasan yang sudah dilaksanakan atau belum dengan melihat kolom pelaksanaan dan disesuaikan dengan pokok bahasan yang akan disampaikan. Sehingga guru mampu mengontrol setiap pokok bahasan dan semua materi bisa tersampaikan sesuai dengan perencanaan.

Dikaitkan dengan hasil observasi, bahwa guru seni tari SD di Malang telah melaksanakan pembelajaran seni tari sesuai dengan program semester yang telah dirancang sebelumnya. Dalam penyampaian materi apresiasi maupun materi ekspresi sudah sesuai dan guru selalu melihat serta memberi tanda setiap standar kompetensi yang telah dilaksanakan pada kolom pelaksanaan. Sehingga guru seni tari telah melaksanakan program semester dengan sebaikbaiknya sebagai acuan pembelajaran seni tari dalam satu semester.

\section{Silabus}

Silabus merupakan sebuah garis besar materi pelajaran yang digunakan untuk menjabarkan lebih lanjut dari standar kompetensi dan kemampuan dasar yang ingin dicapai, dan pokok materi yang perlu dipelajari siswa dalam mencapai standar kompetensi dan kemampuan dasar.

Silabus adalah seperangkat rencana serta pengaturan pelaksanaan pembelajaran dan penilaian yang disusun secara sistematis memuat komponen-komponen yang saling berkaitan untuk mancapai penguasaan kompetensi dasar (Yulaelawati, 2004: 123 dalam Majid, 2008:39). Sesuai dengan teori yang dikemukakan oleh Abdul Majid, 2008: 39 menyebutkan bahwa pada umumnya su- 
atu silabus paling sedikit harus mencakup unsur-unsur:

a. Tujuan mata pelajaran yang akan diajarkan.

b. Sasaran mata pelajaran.

c. Keterampilan yang diperlukan agar dapat menguasai mata pelajaran tersebut dengan baik.

d. Urutan topik-topik yang diajarkan.

e. Aktivitas dan sumber-sumber belajar pendukung keberhasilan pengajaran.

f. Berbagai teknik evaluasi yang digunakan.

Berkenaan dengan komponen silabus lebih rinci dikemukakan oleh Nurhadi (2004:142) dalam Majid (2008:40) bahwa silabus berisi uraian program yang mencantumkan: 1) bidang studi yang diajarkan; 2) tingkat sekolah; 3) pengelompokkan kompetensi dasar; 4) materi pokok; 5) indikator; 6) strategi pembelajaran; 7) alokasi waktu; dan 8) bahan/alat/media.

Berdasarkan hasil dokumentasi yang telah dilakukan diperoleh data bahwa guru seni tari telah menyusun silabus dengan baik disesuaikan dengan kurikulum yang berlaku disekolah. Di dalam silabus terdapat beberapa komponen yang harus diperhatikan diantaranya adalah: Kompetensi dasar, Materi Pokok Pembelajaran, Kegiatan Pembelajaran, Indikator, Penilaian, Alokasi Waktu, dan Sumber Belajar. Untuk perbuatan silabus ini guru seni tari mengacu pada standart kompetensi mengapresiasi karya seni tari dan mengekspresi diri melalui karya seni tari.

a). Materi Apresiasi

Untuk kegiatan pembelajaran pada materi "Apresiasi" adalah: menyaksikan tari dari mancanegara, mendiskusikan ciri-ciri tari yang disaksikan, bertanya jawab tentang keunikan dan keindahan serta pesan dari pertunjukan yang ditonton, mempresentasikan tentang manfaatkan fungsi sosial budaya dari tari yang ditonton, serta menulis pendapat pribadi tentang tari yang ditonton. Dengan bentuk penilaian berupa tes lisan dan tes tulis yang berupa tes uraian dan daftar pertanyaan.

Untuk materi "Apresiasi karya seni tari" kompetensi dasar pertama yang tertulis dalam kompetensi dasar silabus adalah mengidentifikasi karya seni tari mancanegara di Asia, sedangkan pada program semester (Promes) tertulis mengidentifikasi karya seni tari nusantara dan mancanegara. Hal ini sudah sesuai dengan penjabaran dari program semester yang telah dibuat, akan tetapi masih belum sempurna karena karya seni tari nusantara belum tertulis dalam kompetensi dasar silabus dan juga karya seni tari nusantara belum tertulis di dalam kompetensi dasar program semester (Promes).

Untuk sub kompetensi dasar dalam program semester tercantum pada kolom indikator silabus yaitu menentukan asal tari mancanegara, tetapi dalam silabus belum tertulis asal tari nusantara sehingga masih harus disesuaikan lagi dengan program semester (Promes) yang telah dibuat sebelumnya. Begitu juga dengan Kompetensi Dasar dalam silabus kedua yaitu mengidentifikasi tari mancanegara di Asia padahal di dalam program semester tertulis ciri-ciri tari nusantara dan mancanegara. Jadi dalam kompetensi dasar silabus harus ditulis sesuai dengan program semester (Promes).

Di sini ditemukan bahwa untuk sub kompetensi dasar pada program semester yaitu mengidentifikasi ciri-ciri tari nusantara dan mancanegara tertulis dalam kolom indikator silabus tetapi hanya saja yang tertulis ciri-ciri khas tari mancanegara sedangkan ciri-ciri khas tari nusantara tidak tertulis di dalam indikator silabus. Selain itu sub kompetensi dasar program semester (Promes) dalam silabus tercantum pada kolom kompetensi dasar sehingga belum sesuai dengan program semester yang telah dibuat sebelumnya. Temuan lain yang didapatkan peneliti bahwa dalam indikator silabus tertulis "menuliskan keunikan/keindahan dan pesan dari pertunjukkan tari yang ditonton" 
padahal dalam sub kompetensi dasar program semester tidak tertulis demikian.

Untuk Kompetensi Dasar yang kedua dalam program semester (Promes) tertulis menampilkan sikap apresiatif terhadap keunikan tari nusantara dan mancanegara. Disini ditemukan bahwa dalam silabus, kompetensi dasar kedua dalam program semester telah dimasukkan kedalam silabus untuk materi "Ekspresi" yang seharusnya dimasukkan kedalam silabus untuk materi apresiasi, sedangkan sub kompetensi dasar yang terdapat dalam program semester belum semuanya tercantum dalam kolom indikator silabus untuk materi apresiasi, yang tertulis hanyalah mencari komposisi tari, tata rias dan busana, iringan serta poin lain yang tidak tertulis dalam program semester yaitu menyelenggarakan pertunjukkan secara berkelompok. Sehingga kesesuaian antara program semester dan silabus untuk materi apresiasi harus di teliti dan dijabarkan lagi sesuai dengan program semester yang telah dibuat sebelumnya.

b). Materi Ekspresi

Pada materi "Ekspresi" kegiatan pembelajaranya adalah sebagai berikut: menyaksikan tarian mencanegara, mengeksplorasikan konsep garapan tari hasil pengamatan, menemukan gerak dasar untuk garapan tari, dan latihan menarikan garapan tari sesuai dengan konsep dan iringanya.

Bentuk penilaian berupa tes praktik. Hal ini terlihat bahwa dalam materi ekspresi siswa diajak untuk lebih aktif dalam melakukan pencarian gerak serta menemukan iringan musik yang tepat sebagai pendukung gerak yang telah disusun. Dengan demikian, siswa mampu memunculkan kekreatifan dalam mengembangkan ide baru, hal ini sangat berpengaruh pada tingkat keberhasilan suatu pembelajaran yang telah direncanakan sebelumnya. Apabila siswa telah mampu melakukan semua yang direncanakan guru maka pembelajara bisa dikatakan sudah berhasil.
Pada materi "Mengekspresikan diri melalui karya Seni Tari” Kompetensi Dasar yang pertama dalam program semester tertulis "Mengeksplorasi gerak tari kreasi berdasarkan tari mancanegara di Asia". Berdasarkan keterangan tersebut bisa dilihat bahwa kesesuaian antara program semester dan silabus harus diperhatikan kembali agar pelaksanaan pembelajaran sesuai dengan perencanaan yang telah dibuat sebelumnya. Di dalam Kompetensi Dasar pada silabus juga ditemukan adanya Kompetensi Dasar menampilkan tari kreasi mancanegara di Asia padahal Kompetensi Dasar yang terdapat pada program semester hanya memiliki dua kompetensi dasar yaitu mengeksplorasi gerak tari nusantara dan mancanegara serta mengeksplorasi pola lantai dalam tari kelompok. Jadi untuk Komptensi Dasar pada silabus "Menampilkan tari kreasi mancanegara di Asia tidak tercantum dalam program semester.

Pada silabus kolom indikator ditulis berdasarkan sub Kompetensi Dasar dari program semester, di dalam silabus tertulis membuat konsep garan tari hasil pengamatan tari mancanegara padahal dan sub kompetensi dasar pada program semester tertulis hanya mengamati gerak tari saja. Kemudian indikator berikutnya tertulis "Meng kreasi gerak dasar tari sesuai dengan pola konsep garapan sedangkan pada sub kompetensi dasar program semester tidak tercantum demikian tetapi tertulis secara rinci mulai dari menentukan ide tari, melakukan pencarian gerak, dan mengembangkan gerak tari. Maka dari itu untuk poin indikator kedua pada silabus belum ditemukan adanya kesesuaian antara program semester dan silabus, akan tetapi guru dalam perencanaan telah membuat perangkat pembelajaran silabus dan masih diperlukan pembenahan disesuaikan dengan penjabaran program semester.

Dalam kolom kompetensi dasar pada silabus banyak terdapat atau tertulis kompetensi dasar-kompetensi dasar yang ti- 
dak tercantum dalam program semester dan masih ada lagi temuan-temuan yang lain yang tidak tercantum program semester. Akan tetapi di dalam indikator dan kegiatan pembelajaran sudah sesuai dengan materi ekspresi, hanya saja pada perangkat pembelajaran silabus harus disesuaikan kembali dengan program semester. Hal ini sesuai dengan materi karena bisa dilihat dari contoh instrumen yang isinya adalah kalimat perintah dalam pembuatan atau memperagakan gerak tari.

Dengan demikian dapat disimpulkan bahwa guru seni tari dalam pembelajaran seni tari pada kelas IX SMPN 20 Malang telah membuat perangkat pembelajaran silabus. Silabus ini telah disusun berdasarkan standart kompetensi yang akan dicapai serta telah dilaksanakan oleh guru seni tari setiap kali pertemuan. Silabus ini isinya perlu adanya perbaikan lagi dan disesuaikan dengan penjabaran program semester sehingga standar kompetensi maupun kompetensi dasar bisa tercapai. Lebih jelasnya peneliti melampirkan silabus pada daftar lampiran.

\section{Rencana Pelaksanaan Pembelajaran} (RPP)

Pelaksanaan Pembelajaran adalah panduan langkah-langkah yang akan dilakukan oleh guru dalam skenario pembelajaran. Rencana Pelaksanaan Pembelajaran disusun untuk setiap pertemuan yang masingmasing dirancang untuk pertemuan selama 90 menit atau 135 menit. Skenario kegiatan pembelajaran dikembangkan dari rumusan tujuan pembelajaran yang mengacu dari indikator untuk mencapai hasil belajar sesuai dengan kurikulum berbasisi kompetensi (Trianto, 2007:14).

Berdasarkan hasil dokumentasi yang diperoleh bahwa guru seni tari di SMPN di Malang telah membuat Rencana Pelaksanaan Pembelajaran (RPP) di awal semester sebelum pelaksanaan pembelajaran berlangsung sesuai dengan kurikulum yang berlaku di sekolah. Pembuatan rencana pelaksanaan pembelajaran ini didasarkan tetap pada standar kompetensi dasar yang ingin dicapai.

Dalam rencana pelaksanaan pembelajaran yang telah dibuat ini memiliki komponen-komponen tanpa menggunakan tabel atau kolom-kolom seperti prota, promes, dan silabus. Sebelum komponenkomponen dibuat, pertama kali yang ditulis adalah nama sekolah, mata pelajaran, kelas/semester, dan alokasi waktu agar jelas dalam melaksanakan pembelajaran. Adapun komponen-komponen yang terdapat dalam rencana pelaksanaan pembelajaran yang telah dibuat antara lain: Standar Kompetensi, Kompetensi Dasar, Indikator, Tujuan Pembelajaran, Materi Pembelajaran, Metode, Sumber Belajar, Strategi Pembelajaran dan Penilaian. Komponen-komponen tersebut berlaku untuk materi apresiasi maupun materi ekspresi sehingga dengan adanya rencana pelaksanaan pembelajaran ini pembelajaran bisa lebih efektif karena semua telah direncanakan.

a). Materi Apresiasi

Rencana Pelaksanaan Pembelajaran pada materi "Mengapresiasikan karya seni tari nusantara dan mancanegara" memiliki kompetensi dasar mengidentifikasi dan menampilkan sikap apresiatif terhadap jenis dan keunikan karya seni tari nusantara dan mancanegara, dengan indikator menyebutkan ciri-ciri tari nusantara dan mancanegara serta menyebutkan daerah/negara asal tarian.

Hasil dokumentasi, adapun tujuan pembelajaran yang ingin dicapai guru dalam materi apresiasi adalah: siswa mempunyai wawasan tentang tarian nuasantara dan mancanegara, mendiskusikan tanggapan siswa terhadap keunikan tari nusantara dan mencanegara, mempresentasikan hasil diskusi, dan membuat uraian secara tertulis dan lisan mengenai tanggapan tersebut. Metode yang digunakan guru dalam penyampaian materi adalah dengan menggunakan metode ceramah, tanya jawab, pemberian informasi, demonstrasi, dan penugasan. 
Adapun strategi pembelajaran yang dilakukan oleh guru dalam pembelajaran seni tari pada materi apresiasi adalah sebagai berikut: pada pendahuluan guru menyampaikan tujuan dari pembelajaran, dilanjutkan dengan tanya jawab sekitar materi pembelajaran. Kegiatan inti: (1) guru menjelaskan tentang ciri-ciri tari nusantara dan mancanegara, dalam hal ini guru melalukan metode ceramah dalam menyampaikan materi. (2) guru berinteraksi dengan siswa yaitu dengan mengadakan tanya jawab seputar materi yang telah dijelaskan, dalam RPP ini bisa terlihat bahwa adanya interaksi antara guru dengan siswa baik secara individu maupun kelompok dalam pembelajaran. (3) Mendiskusikan ciri-ciri tari nusantara dan mancanegara, disini bisa dilihat adanya interaksi siswa antar siswa dalam mendiskusikan ciri-ciri tari nusantara dan mencanegara sesuai tugas yang diberikan. (4) Menyaksikan dan mengamati tari nusantara dan mancanegara melalui tayangan VCD. (5) Menulis keunikan tarian nusantara dan mancanegara. 6) Mempresentasikan hasil diskusi kelompok, bisa dilihat bahwa dalam RPP siswa mampu berinteraksi dengan kelompok lain yang komunikatif melakukan diskusi. Di akhir pelajaran guru menutup pelajaran dengan membuat kesimpulan dari hasil diskusi kelompok.

Guru dalam pembelajaran seni tari memiliki kekreatifan dalam menyampaikan materi, yaitu selain menggunakan metode ceramah guru juga menggunakan tampilan VCD agar suasana kelas tidak menjenuhkan. Dan guru juga membuat siswa lebih aktif dalam pembelajaran yaitu dengan membuat kelompok belajar yang menuntut siswa berinteraksi dengan siswa lain dalam menyelesaikan tugas yang diberikan.

Berdasarkan hasil dokumentasi yang di dapat bahwa Rencana Pelaksanaan Pembelajaran untuk standar kompetensi "Kemampuan mengapresiasikan karya seni tari nuasantara dan mancanegara" telah ditemukan bahwa Kompetensi dasar yang terdapat dalam rencana pelaksanaan pembelajaran (RPP) yaitu mengidentifikasi dan menampilkan sikap apresiatif terhadap jenis dan keunikan karya seni tari nusantara dan mancanegara. Sedangkan berdasarkan silabus hanya tertulis mengidentifikasi karya seni tari mancanegara di Asia dan tidak tertulis menampilkan sikap apresiatif terhadap jenis dan keunikan karya seni tari nesantara dan mancanegara, bahkan di dalam silabus untuk Kompetensi Dasar apresiasi terhadap jenis dan keunikan karya seni tari dan mancanegara tidak diposisikan pada Kompetensi Dasar materi apresiasi tetapi dicantumkan pada Kompetensi Dasar materi ekspresi. Dapat dilihat bahwa untuk rencana pelaksanaan pembelajaran (RPP) dan silabus masih belum sesuai dan harus dilakukan pembenahan sesuai dengan penjabaran silabus.

Bila dilihat berdasarkan program semester diketahui untuk dua kompetensi dasar yang tercantum dalam program Semester untuk materi apresiasi yaitu mengidentifikasi karya seni tari nusantara dan mancanegara serta menampilkan sikap apresiatif terhadap keunikan tari nusantara dan mancanegara, di dalam rencana pelaksanaan pembelajaran kedua Kompetensi Dasar yang terdapat pada program semester telah dijadikan satu dalam Kompetensi Dasar rencana pelaksanaan pembelajaran tertulis "Mengidentifikasi dan menampilakan sikap apresiatif terhadap jenis dan keunikan karya seni tari nusantara danmancanegara". Dapat dilihat dan dikatakan bahwa antara rencana pelaksanaan pembelajaran dan program semester sudah sesuai dan berbeda hanya pada pemisahan saja. Begitu juga bila dilihat berdasarkan program tahunan bahwa kompetensi dasar yang telah dibuat dalam rencana pelaksanaan pembelajaran sudah sesuai dengan Kompetensi Dasar yang tercantum pada program tahunan.

b). Materi Ekspresi

Pada materi "Mengekspresikan diri melalui karya seni tari" memiliki kompetensi dasar mengeksplorasikan gerak tari 
nusantara dan mancanegara serta menciptakan gerak tari kreasi, dengan indikator mengembangkan dan mengkreasikan gerak tari nusantara dan mancanegara, memperoleh gerakan baru dari hasil eksplorasi, dan menyusun komposisi gerak tari secara sederhana.

Berdasarkan hasil dokumentasi, adapun tujuan pembelajaran yang ingin dicapai guru dalam materi ekspresi adalah: siswa dapat melakukan eksplorasi gerak, menciptakan gerakan baru, dan membuat komposisi sederhana. Disini guru lebih sering menggunakan demonstrasi dalam penyampaian materi karena materi lebih banyak ditekankan pada aspek gerak.

Adapun strategi pembelajaran yang dilakukan oleh bu Umi dalam pembelajaran seni tari pada materi "ekspresiasi" adalah sebagai berikut: pada kegiatan pendahuluan yang dilakukan oleh guru yaitu mengondisikan kelas dan menyampaikan tujuan pembelajaran. Kemudian memasuki kegiatan inti: 1) Guru menjelaskan dan memperagakan tekhnik gerak dasar, kemudian siswa menirukan dan mengembangakan sesuai dengan kreatifitas masing-masing siawa dan kelompoknya, disini bisa dilihat adanya interaksi antara guru siswa dalam pembelajaran seni tari. 2) Siswa harus mampu menciptakan gerak baru melalui pengembangan gerak dasar, disini terlihat bahwa dituntut untuk aktif dalam membuat gerakan baru dengan acuan contoh yang diberikan guru diawal pelajaran. 3) Siswa membuat gerakan disesuaikan dengan ide dan tema tari yang sudah ditentukan secara berkelompok, dari sini bisa dilihat bahwa nantinya siswa aktif dalam malakukan pencarian ide baru kemudian siswa berani mengemukakan pendapatnya kepada teman kelompok, kemudian melakukan latihan tari sesuai komposisi yangsudah dirancang bersama kelompok. Diakhir pelajaran bisa dilihat bahwa kegiatan yang dilakukan adalah menyimpulkan hasil pembelajaran dan hasil latihan bersama.
Dari paparan diatas dapat disimpulkan bahawa rencana pelaksanaan pembelajaran tari SD di Malang telah dibuat dan dilaksanakan. Namun guru seni tari sebaiknya melakukan perbaikan dalam menyusun RPP dan harus disesuaikan dengan perangkat pembelajaran yang telah dibuat sebelumnya. Sehingga pembelajaran akan berjalan sesuai dengan rencana dalam pencapaian hasil belajar yang optimal, dan hal ini juga sudah memenuhi dan sesuai dengan pembelajaran PAKEM yaitu telah membuat kelengkapan pembelajaran.

\section{B. Pelaksanaan pembelajaran seni tari pada di SD di Malang}

Hasil observasi yang dilakukan serta wawancara dengan guru mengenai pembelajaran seni tari sesuai perangkat pembelajaran yang dibuat (RPP) pada materi ekspresi dengan Standar Kompetensi mengekspresikan diri melalui karya seni tari dan Kompetensi Dasar mengeksplorasi gerak tari nusantara dan mancanegara serta menciptakan gerak tari kreasi dikaitkan dengan teori pendekatan PAKEM adalah sebagai berikut.

\section{Keterampilan Mengajar}

Keterampilan mengajar merupakan ketrampilan yang harus dimiliki dan diperhatikan guru sebelum memulai pelajaran, sehingga apa yang menjadi tujuan pembelajaran tercapai dengan baik. Kedudukan guru mempunyai arti penting dalam pendidikan. Arti penting itu bertolak dari tugas dan tanggung jawab guru yang cukup berat untuk mencerdaskan anak didiknya. Guru harus melengkapi dirinya dengan berbagai keterampilan mengajar. Hal ini sesuai dengan teori yang dikemukakan oleh Djamarah (2000: 99) bahwa ketrampilan dasar mengajar adalah ketrampilan yang mutlak harus dimiliki guru agar dapat mengoptimalkan peranannya di kelas. Adapun komponen keterampilan mengajar adalah sebagai berikut: 
a. Membuka Pelajaran

Menurut Paranto dkk (1983: 26) membuka pelajaran adalah usaha atau kegiatan yang dilakukan oleh guru dalam proses belajar mengajar untuk menciptakan prakondisi bagi murid agar mental maupun perhatiannya terpusat pada apa yang akan dipelajarinya sehingga memberikan efek positif terhadap kegiatan belajar. Tujuan pokok membuka pelajaran adalah: (1) Untuk memenyiapkan mental murid agar siap memasuki persoalan yang akan dibicarakan (2) Untuk menimbulkan minat serta pemusatan perhatian murid terhadap apa yang akan dibicarakan dalam kegiatan belajarmengajar.

Sesuai dengan hasil observasi yang dilakukan, pelaksanaan membuka pelajaran oleh guru seni tari dalam pembelajaran adalah dengan jalan mengucapkan salam, berdoa, guru melakukan presensi siswa secara menyeluruh dengan memanggil satu persatu siswa, kemudian guru mengulang materi minggu lalu sebelum memasuki atau melanjutkan materi baru dengan harapan siswa dapat merefresh kembali (mengingat kembali) materi sebelumnya sehingga tidak lupa begitu saja, selain itu siswa bisa siap dan perhatian akan terpusat terhadap apa yang akan dibicarakan. Guru sebelum memasuki materi, terlebih dahulu membuat kaitan antara materi dengan pengalaman dari siswa. Hal ini sesuai dengan teori yang dikemukakan oleh Trianto (2000: 139) yakni: "Komponen lain dari ketrampilan membuka pelajaran adalah membuat kaitan atau hubungan diantara materi-materi yang akan dipelajari dengan pengalaman dan pengetahuan yang dikuasai anak didik".

Dalam pertemuan ini masih dalam lingkup materi ekspresi sehingga guru memberikan pengarahan sebelum pindah ke ruang praktik yaitu aula. Selain itu guru memberikan gambaran kepada siswa terlebih dahulu tentang materi dan tugas yang akan diberikan sehingga siswa paham betul dengan tugas yang diberikan.
Sedangkan untuk materi apresiasi guru hanya menggunakan ruang kelas saja sebagai fasilitas karena sudah dirasa cukup dalam pembelajaran seni tari yang lebih menekankan pada pemahaman teori bukan praktik dan dalam membuka pelajaran guru memberikan pertanyaan tentang materi minggu lalu sehingga siswa siap menerima pelajaran berikutnya. Hal ini senada dengan yang diungkapkan oleh Trianto (2000:139) bahwa guru dalam membuka pelajaran dilakukan dengan set induction, yakni usaha atau kegiatan yang dilakukan guru dalam kegiatan interaksi edukatif untuk menciptakan prakondisi bagi anak didik agar mental maupun perhatianya terpusat.

Berdasarkan hasil observasi yang dilakukan dapat disimpulkan bahwa guru dalam pembelajaran seni tari SD di Malang telah melaksanakan kegiatan membuka pelajaran dengan baik. Dikaitkan dengan teori PAKEM sudah sesuai karena guru membuat kaitan antara pengetahuan dan pengalaman siswa dengan materi yang diberikan.

\section{b. Mengadakan Variasi}

Variasi adalah suatu kegiatan guru dalam konteks interaksi belajar mengajar yang ditujukan untuk mengatasi kebosanan murid sehingga dalam situasi proses belajar mengajar murid selalu menunjukkan ketekunan, antusias serta penuh partisipasi. Menurut S.L.La Sulo (1983: 52) Aspek-aspek yang perlu diperhatikan dalam mengadakan variasi adalah sebagai berikut:

\section{Gerak Guru (Teacher Movement)}

Guru diharapkan bila sudah di depan kelas harus bisa bergerak bebas didalam kelas, hal ini terkandung maksud sambil memberikan dorongan dan menanamkan rasa dekat pada murid sekaligus bisa mengontrol tingkah laku murid, jadi murid tidak merasa takut untuk bertanya kepada guru.

2.Isyarat Guru (Teacher Gesture)

Maksudnya adalah gerak tubuh anggota badan yang mengandung arti atau maksud tertentu untuk menimbulkan perhatian, rangsangan pada murid pada proses 
belajar mengajar. Misalnya: mengkerutkan kening bila tidak setuju dan tidak paham apa yang disampaikan siswa, anggukan kepala berarti berarti sebagai tanda setuju dengan gagasan siswa, serta gerak tangan yang menggambarkan atau menyatakan sesuatu dan sebagainya.

\section{Gaya Interaksi (Interaction Styles)}

Menghindarkan kebosanan, kejemuan serta untuk menhidupkan suasana kelas demi keberhsilan murid mencapai kemampuan yang telah ditentukan oleh tujuan pelajaran maka dituntut adanya pola hubungan antara guru dan siswa, dalam proses belajar mengajar yang sering disebut sebagai gaya interaksi yang terdiri dari tiga macam.

a. Guru-Kelompok murid. Guru menyajukan pertanyaan kepada seluruh kelas bukan kepada murid tertentu secara individual.

b. Guru-Murid sebagai individu. Guru memberikan pernyataan atau pertanyaan langsung ditujukan kepada salah seorang murid tertentu.

c. Murid-Murid. Setelah guru memberikan pengarahan kemudian pertanyaan atau permasalahan dilontarkan ke kelas agar terjadi diskusi antara murid dalam menyelesaikan permasalahan tersebut.

Sesuai dengan observasi yang dilakukan, gerak guru (Teacher Movement) di dalam kelas bergerak dengan bebas tanpa rasa kikuk serta lancar akan menyampaikan materi sehingga siswa merasa nyaman, tidak takut dan merasa dekat. Hal ini bisa dijadikan guru untuk mengkontrol tingkah la$\mathrm{ku}$ siswa. Dalam menerangakan dan memberikan penjelasan materi kepada siswa sesekali guru melakukan gerakan sederhana yang mengandung suatu makna tertentu atau bisa dikatakan sebagai sebuah isyarat. Misalnya saja guru dalam proses pembelajaran seni tari mengkerutkan kening sebagai tanda bahwa guru tidak paham dengan apa yang dikatakan siswa dan menganggukkan kepala bila setuju dengan pernyataan atau pertanyaan siswa. Hal ini bisa dilakukan sebagai penimbul perhatian serta rangsangan kepada siswa selama proses belajar mengajar berlangsung.

Ada kalanya didalam suasana belajar bisa jadi menjenuhkan dan membosankan, untuk mengantisipasi hal tersebut guru seni tari di SD di Malang dengan cara melakukan interaksi kepada siswa seperti interaksi guru dengan kelompok murid dengan mengajukan pertanyaan kepada seluruh kelas, interaksi guru dengan murid sebagai individu dengan mengajukan pertanyaan langsung pada salah seorang siswa, dan interaksi siswa-siswa dngan jalan setelah dirasa cukup dalam memberikan pengarahan kemudian melontarkan permasalahan ke kelas sehingga terjadi diskusi antar murid dalam menyelesaikan permasalahan tersebut.

Hal ini sudah sesuai dengan salah satu prinsip PAKEM yaitu adanya interaksi antara peserta didik itu sendiri maupun guru baik melalui pembelajaran menjadi lebih hidup dan menarik (Pembekalan Tim Widyaiswara 2009:12).

Variasi melalui gaya interaksi, guru seni tari melakukan variasi lain dalam proses pembelajaran seni tari yaitu dengan cara memperhatikan latar belakang masingmasing siswa yang berbeda sehingga membutuhkan penanganan yang berbeda pula. Misalnya saja ada kelompok yang tingkat pemahamanya tinggi maka guru hanya membimbing dan mengarahkan pada pengembangan berikutnya, sedangakan pada kelompok yang tingkat pemahamanya kurang maka guru memberikan perlakuan khusus dan memberikan motivasi.

Hal ini sudah berkaitan dengan teori PAKEM yaitu guru aktif dalam memberikan motivasi kepada siswa serta memantau kegiatan belajar siswa. Berdasarkan hasil observasi yang dilakukan bahwa guru dalam pembelajaran seni tari SD di Malang telah mengadakan variasi pembelajaran sesuai dengan pembelajaran PAKEM. 


\section{c. Memberikan Penguatan (Reinforcement)}

Penggunaan penguatan yang tepat dalam proses belajar mengajar dapat menimbulkan pengaruh yang berupa sikap yang lebih positif dari pihak murid sehingga partisipasinya dalam proses belajar mengajar akan meningkat, dengan begitu dapat diharapkan bahwa pencapaian prestasi belajar mengajar menjadi lebih tinggi.

Sesuai dengan hasil observasi dan wawancara yang telah dilakukan, diketahui guru dalam pelaksanaan pembelajaran seni tari memberikan penguatan kepada siswa dengan cara memberikan pujian sebagai penghargaan atas hasil kerja yang telah dilakukan serta guru menanamkan kepada siswa bahwa seni itu tidak ada yang salah, jadi dalam seni tari apapun bentuk geraknya tidak jadi masalah asalkan tau maksud dari gerakan tersebut, dengan demikian siswa tidak merasa takut untuk bergerak.

Guru dalam memberikan penguatan berdasarkan apa yang telah dilakukan siswa, misalnya guru melihat siswanya ragu dalam melakukan gerakan serta merasa tidak percaya diri maka guru menguatkan kepada siswa dengan memberikan motivasi atau dorongan bahwa apa yang dilakukan siswa tersebut tidak salah dan memberi semangat agar siswa lebih percaya diri. Selain itu guru selalu memberikan pujian setiap apa yang dilakukan siswa meskipun gerakan yang dilakukan masih jauh dari sempurna. Hal inilah yang dilakukan oleh guru seni tari dalam pembelajaran agar tercapai tujuan pembelajaran yaitu siswa mam pu malaksanakan perencarnaan yang telah dibuat oleh guru.

Demikian dapat disimpulkan bahwa guru dalam pembelajaran seni tari pada di SMPN di Malang telah memberikan penguatan kepada siswa sebagai bentuk perhatian guru kepada siswa dalam proses pembelajaran.

d. Penyampaian Materi

Awal terjadinya komunikasi antara guru dan siswa di kelas adalah di awali de- ngan penyampaian informasi dari guru kepada siswa. Informasi yang disampaikan itu bukan hanya menyangkut masalah apa yang harus dikerjakan siswa, tetapi juga menyangkut masalah lainya seperti memberi petunjuk, pengarahan, dan apresepsi yang divariasikan dalam berbagai bentuk tanpa menyita banyak waktu untuk kegiatan pokok (Djamarah, 2000:74).

Berdasarkan hasil observasi yang dilakukan bahwa guru seni tari sebelum memulai menyampaikan materi terlihat penampilan yang semangat, antusias dengan raut wajah yang gembira. Hal ini dilakukan guru agar siswa memiliki kesan bahwa pelajaran yang akan mereka dapatkan bukanlah pelajaran yang menakutkan dan siswa akan lebih merasa siap menerima pelajaran dengan sikap antusias yang diperlihatkan oleh guru serta semangat secara otomatis akan timbul dari dalam diri siswa.

Dalam penyampaian materi guru terlihat sangat menguasai materi yang disampaikan dengan bukti bahwa guru jarang bahkan tidak pernah melakukan kesalahan dalam pemberian materi dan semua didasarkan pada teori yang berhungan dengan materi yang akan disampaikan sehingga guru tidak asal dalam menyampaikan materi. Sesekali guru disela-sela penyampaian materi memanfaatkan humor agar suasana belajar tidak terasa tegang, cara guru dalam meman faatkan humor adalah dengan mengajak siswa berkomunikasi dan berbincang tentang pembelajaran dikaitkan dengan konteks pengalaman sehari-hari serta guru biasanya bercerita tentang pengalaman lucu yang per nah dialami guru dalam mengajar kelas lain. Hal tersebut dilakukan oleh guru hanya sebagai pembangkit suasana agar tidak menjenuhkan, guru melakukanya sekitar 35 menit saja kemudian melanjutkan kembali lagi dalam memberikan materi. Hal ini juga bisa menimbulkan keceriaan dan antusias siswa dalam belajar seni tari.

Dapat dilihat bahwa guru telah menciptakan kegiatan pembelajaran yang me- 
nyenangkan dan membuat siswa merasa nyaman tanpa merasa jenuh sehingga pembelajaran bisa dilakukan secara optimal, hal ini sudah sesuai dengan teori PAKEM yaitu pembelajaran yang menyenangkan dan ti dak membuat anak merasa tertekan.

Demikian dapat disimpulkan bahwa guru dalam penyampaian materi sangat menguasai materi serta bisa memanfaatkan humor sebagai pembangkit semangat siswa dan suasana kelas akan terhindar dari rasa jenuh dan dalam suasana pembelajaran yang menyenangkan.

e. Menutup Pelajaran

Menutup pelajaran menurut Sulo adalah suatu bentuk kegiatan yang dilakukan oleh guru untuk mengakhiri kegiatan belajar mengajar. Sedangkan menutup pelajaran (closure) menurut Djamarah (2000:140) adalah mengakhiri kegiatan interaksi edukatif untuk memberikan gambaran menyeluruh tentang apa yang telah dipelajari anak didik, mengetahui tingkat pencapaian anak didik dan tingkat keberhasilan guru dalam proses interaksi edukatif.

Hasil observasi oleh peniti bahwa pembelajaran seni tari di SMPN 20 Malang diakhir pelajaran guru menyuruh siswa memperagakan hasil belajar yang mereka peroleh selama pembelajaran berlangsung, selanjutnya guru mengevaluasi atau melakukan refleksi terhadap hasil yang dibuat siswa kemudian pemberian nilai. Pemberian nilai sebenarnya dilakukan oleh guru tidak hanya pada hasil akhir saja tetapi guru melakukan penilaian tersebut setiap kali pertemuan praktik tari. Setelah mengevaluasi guru menginformasikan untuk tugas berikutnya yaitu siswa ditugaskan untuk mengembangkan gerak tari yang telah mereka buat menjadi satu rangkaian gerak sederhana, selanjutnya guru mengakhiri dengan doa.

Guru sebelum menutup pelajaran selalu melihat perangkat pembelajaran untuk mengetahui dan mengkontrol perencanaan pembelajaran (RPP) yang sudah atau pun belum dilaksanakan sehingga guru tidak melenceng dari rencana yang sudah dibuat sebelumnya. Di setiap guru menutup pelajaran teori dan sebelum memulai materi prak tik guru selalu mengatakan siswa bahwa tugas yang diberikan akan dinilai sebagai evaluasi tetapi itu hanyalah suatu trik dari guru agar siswa tidak menyepelekan tugas yang diberikan dan secara otomatis siswa akan berusaha dengan sebaik mungkin dalam menyelesaikan tugas tersebut sampai jam pelajaran usai. Diakhir pelajaran, doa dilakukan sebagai tanda bahwa pembelajaran berakhir, disini guru menjadi pemimpin doa kemudian diakhiri dengan salam penutup.

Demikian dapat disimpulkan bahwa guru seni tari dalam proses pembelajaran telah melakukan kegiatan menutup pelajaran.

\section{Pengelolaan Kelas}

Dalam materi ekspresi sesuai dengan hasil observasi, adapun pengelolaan kelas yang dilakukan oleh guru adalah guru membentuk kelompok yang masing-masing kelompok terdiri dari 6-7 orang, dan guru memberikan kebebasan kepada siswa untuk memilih sendiri anggota kelompoknya. Hal ini sesuai dengan yang dikemukakan oleh Djamarah (2000: 181) bahwa dalam pembentukkan kelompok didasarkan pada kesenangan berkawan, sehingga siswa dapat menentukan sendiri anggota kelompoknya dan dalam hal ini siswa akan lebih terbuka dalam berbuat hal yang sama. Pada pertemuan sebelumnya siswa diminta mengeksplorasi gerak berdasarkan tema diawali dari gerak alami atau gerak dasar yang belum distilisasi kemudian dibuat gerak maknawi (gerak yang memiliki makna) secara individu dan hasilnya adalah sebuah produk tari yang secara murni dibuat oleh siswa yang kemudian dinilai oleh guru seni tari. Gerak maknawi dipilih guru seni budaya dalam penugasan siswa untuk mengeksplorasi gerak karena pada Sekolah Menengah Pertama merupakan tahapan awal bagi siswa dalam mengenal dan memahami gerak tari dan mereka akan lebih mudah menyerap 
materi jika setiap gerakan didasarkan pada gerak maknawi sehingga minimal mereka memahami makna gerakan yang telah mereka buat.

Setelah dibuat kolompok-kelompok belajar guru menugasi masing kelompok untuk mencari gerakan berdasarkan tema yang telah mereka pilih dan tentukan sebelumnya kemudian siswa mengaplikasikannya dengan iringan musik yang sesuai dengan tema, siswa begitu sibuknya dalam mencari gerakan yang cocok dengan tema yang mereka tentukan. Hal ini sesuai dengan teori inkuiri yaitu menemukan sendiri dari hasil pengamatan dan berdasarkan pengalaman mereka sendiri. Menurut Masnur (2008: 44) menemukan atau (inquiry) adalah:

"kegiatan yang diawali dari fenomena, dilanjutkan dengan kegiatan-kegiatan bermakna untuk menghasilkan temuan yang diperoleh sendiri oleh siswa. Dengan demikian pengetahuan dan ketrampilan yang diperoleh siswa tidak dari hasil mengingat seperangkat fakta, tetapi hasil menemukan sendiri dari fakta yang dihadapinya".

Hal ini juga terlihat interaksi antar siswa yang begitu aktif dalam mengemukakan gagasan mereka terhadap teman yang lain, kekreatifan mereka juga muncul hal ini terlihat pada saat siswa berani memunculkan ide-ide baru dalam membuat gerakan sehingga mereka dapat memilih gerakgerak yang sesuai dengan tema serta mengolah gerakan yang telah mereka temukan dalam sebuah rangkaian gerak tari yang indah kemudian disesuaikan dengan musik yang telah ditentukan. Secara aktif siswa antar siswa dalam kelompok saling memberikan motivasi kepada teman yang kurang bagus gerakanya, sehingga dalam kelompok tersebut terjadi suatu interaksi yang memunculkan kekompakan dan hasil yang baik. Hal ini senada dengan yang dikemukakan oleh Sediono (2001:8) bahwa secara garis besar dalam Pembelajaran Aktif, Efektif, dan Menyenangkan (PAKEM) dian- taranya dari segi siswa aktif dalam mengemukakan pendapat serta kreatif dalam menemukan atau membuat sesuatu.

\section{Interaksi Guru Siswa}

Di dalam suatu proses pembelajaran faktor yang paling penting adalah adanya interaksi antara guru dengan siswa. Keduanya memiliki hubungan timbal balik dalam pembelajaran yaitu guru sebagai fasilitator dan informan dalam proses pembelajaran. Dengan adanya interaksi inilah proses penyampaian materi akan lebih mudah dan komunikatif serta tidak ada rasa takut dari siswa untuk bertanya apa yang belum mereka pahami.

Berdasarkan hasil observasi di kelas, pada proses pembelajaran seni tari SD di Malang antara guru dengan siswa terlihat samasama aktif berinteraksi dalam proses pembelajaran. Hal tersebut senada dengan teori yang dikemukakan Tim Widyaiswara (2009:12)

"Bahwa dalam pembelajaran PAKEM harus selalu ada dan terjaga interaksi anatara peserta didik itu sendiri maupun melalui metode lainya, karena dengan interaksi inilah pembelajaran menjadi lebih hidup dan menarik".

Hal ini terlihat interaksi antara guru dengan siswa pada saat pembelajaran berlangsung yaitu guru memberikan materi kepada siswa dan memberikan penjelasan seputar materi yang akan disampaikan, akan tetapi guru disini tidak langsung memberikan semua materi kepada siswa tetapi sebagai bentuk interaksi guru hanya sebagian memberikan materi, kemudian guru memancing pengetahuan siswa dengan memberikan pancingan berupa pertanyaan. Demikian diharapkan siswa mampu mengaplikasikan pengalaman pribadi pengetahuan yang mereka dapat sendiri dengan materi yang diberikan. Siswa pun terlihat antusias dalam mengikuti setiap penjelasan yang disampaikan. Hal ini ternyata juga sesuai dengan karakteristik dari pendekatan model CTL (Contextual Teaching and Learning) 
yaitu menggabungkan dari hasil pengalaman dengan materi baru, yang senada dikemukaan oleh Muslich (2008:41) bahwa salah satu karakteristik pendekatan CTL (Contextual Teaching and Learning) adalah Relating, yaitu bentuk belajar dalam konteks kehidupan nyata, pembelajaran harus digunakan untuk menghubungkan situasi sehari-hari dengan informasi baru untuk dipahami atau dengan problema untuk dipecahkan.

Selain itu guru dalam melakukan interaksi terhadap siswa dalam proses pembelajaran adalah dengan cara menggunakan penerapan metode pembelajaran. Adapun penerapan metode dalam penyampaian materi adalah: (1) Guru menggunakan metode ceramah; (2) Tanya Jawab; (3) Pemberian infomasi; (4) Demonstrasi; dan (5) Penugasan. Kesemuanya itu dilakukan oleh guru sebagai cara untuk berinteraksi dengan siswa untuk mendukung proses pembelajaran.

Dikatakan bahwa dalam pembelajaran seni tari di SMPN 20 Malang sudah ada interaksi antara guru dan siswa dalam mendukung proses pembelajaran.

\section{Sarana Prasarana}

Salah satu penunjang dan pendukung proses belajar mengajar adalah adanya sarana prasarana yang memadai sebagai alat, guna memperlancar proses pembelajaran pembelajaran. Berdasarkan hasil observasi bahwa SD di Malang pada pembelajaran seni tari telah memiliki fasilitas penunjang yaitu berupa tape recorder, VCD player sebagai penunjang pembelajaran pada materi ekspresi. Selain itu ruang belajar seni tari sudah cukup mendukung yaitu selain ruang kelas untuk materi apresiasi dan teori, juga memiliki ruang aula sebagai kelas untuk materi ekspresi sehingga siswa bisa dengan leluasa untuk bergerak dan mengeksplorasi sesuai dengan tema yang telah ditentukan. Ruang untuk materi ekspresi ini memiliki luas kira-kira $18 \times 9 \mathrm{~m}^{2}$ dengan ventilasi yang cukup serta cahaya yang masuk juga banyak, jadi ruangan memadai untuk proses pembelajaran dan tidak lembab. Fasilitas-fa silitas yang ada ini diharapkan mampu menunjang pembelajaran seni tari. Dalam pelaksanaanya terlihat bahwa siswa juga ikut terlibat dalam penggunaan media pembelajaran yang ada misalnya dalam menggunakan VCD player.

\section{e. Evaluasi}

Penilaian yang sesuai dengan pembelajaran model PAKEM adalah penilaian otentik yang merupakan proses pengumpulan informasi oleh guru tentang perkembangan dan pencapaian pembelajaran yang dilakukan oleh peserta didik melalui berbagai teknik yang mampu mengungkapkan, membuktikan atau menunjukkan secara tepat bahwa tujuan pembelajaran telah benarbenar dikuasai dan dicapai.

Tujuan Penilaian otentik itu sendiri adalah untuk: (a) Menilai Kemampuan Individual melalui tugas tertentu; (b) Menentukan kebutuhan pembelajaran; (c) Membantu dan mendorong siswa; (d) Membantu dan mendorong guru untuk mengajar yang lebih baik; (e) Menentukan strategi pembelajaran; (f) Akuntabilitas lembaga; dan (g) Meningkatkan kualitas pendidikan.

Bentuk penilaian tes dapat dilakukan secara lisan, tertulis, dan perbuatan. Sementara itu, bentuk penilaian non tes dilakukan dengan menggunakan skala sikap, cek lis, kuesioner, studi kasus, dan portofolio. Dalam pembelajaran, dengan pendekatan PAKEM rangkaian penilaian ini seyogiayanya dilakukan oleh seorang guru. Hal ini disebabkan setiap jenis atau bentuk penilaian tersebut memiliki beberapa kelemahan selain keunggulan (Anwar Fuady, 2008)

Pada akhir pembelajaran guru harus melakukan evaluasi terhadap hasil tes dan menetapkan standar keberhasilan. Evaluasi terhadap hasil belajar bertujuan untuk mengetahui ketuntasan siswa dalam menguasai kompetensi dasar. Dengan mengadakan evaluasi ini guru bisa melihat kompetensi dasar, materi, atau indikator yang belum dicapai. Menurut Nana Sudjana (2008:24) 
evaluasi adalah pemberian keputusan tentang nilai sesuatu yang mungkin dilihat dari segi tujuan, gagasan, cara bekerja, pemecahan, metode, dan materi. Evaluasi juga bisa dilihat keberhasilan siswa dalam proses pembelajaran dan mengadakan perbaikan bila siswa gagal, kemungkinan yang bisa terjadi adalah apakah instrumen yang diberikan terlalu sulit, atau cara pembelajaran yang digunakan kurang tepat. Sehingga guru bisa sekaligus mengevaluasi diri sendiri mengenai metode pembelajaran yang digunakan sudah tepat atau belum.

Berdasarkan hasil observasi dalam pembelajaran seni tari pada kelas IX guru mengadakan evaluasi setiap kali selesai mempelajari suatu unit pembelajaran atau bisa disebut sebagai evaluasi formatif. Menurut Djamarah (2000:214) hal-hal yang berhubungan dengan masalah evaluasi formatif adalah:

1) Penilaian dilakukan pada akhir pelajaran.

2) Penilaian formatif bertujuan mengetahui sejauh mana tujuan instruksional khusus pada setiap satuan pelajaran yang telah tercapai.

3) Penilaian formatif dilakukan dengan mempergunakan tes hasil belajar, kuosioner, atau cara lainya yang sesuai.

4) Siswa dinilai berhasil dalam penilaian formatif jika mencapai taraf penugasaan sekurang-kurangnya $75 \%$ dari tujuan yang ingin dicapai.

Materi ekspresi guru melakukan evaluasi dengan cara melakukan penilaian terhadap presentasi masing-masing kelompok dalam memperagakan hasil perolehan siswa dalam mengeksplorasi gerakan, disini guru melakukan penilaian secara individu dan kelompok dan penilaian ini dilakukan berdasarkan penilaian otentik yaitu penilaian sebenarnya apa yang diperoleh sis wa. Dari sini bisa dilihat bahwa guru meng gunakan jenis alat evaluasi berupa tes perbuatan (Performance Test), yaitu tes yang diberikan dalam bentuk tugas-tugas yang pelaksanaanya dalam bentuk penampilan atau per- buatan antara lain: praktik kerja lapangan, praktik olahraga, praktik laboratorium, praktik kesenian dan sebagainya (Djamarah, 2000:219).

Berdasarkan hasil wawancara penilaian individu dalam kelompok dilakukan oleh guru agar siswa lebih aktif dan bersungguhsungguh dalam mengerjakan tugas yang diberikan, serta secara otomatis siswa tidak akan tergantung pada kerja kelompok yang melibatkan siswa tertentu saja, tetapi siswa akan bekerja bersama-sama dalam suatu kelompok untuk menghasilkan yang terbaik. Penilaian kelompok, kriteria penilaian yang digunakan oleh guru yaitu: kekompakan, kreatifitas dalam mengesplorasi gerak, kesesuaian gerak berdasarkan iringan, serta bentuk panyajian yang dilakukan kelompok. Sebelum melakukan penilaian, guru memberikan petunjuk (instruksi) yang jelas sehingga siswa mengetahui secara tepat apa yang harus dilakukanya.

Dalam materi apresiasi guru juga melakukan penilaian baik secara individu maupun kelompok. Berdasarkan wawancara untuk penilaian individu, guru memberikan tugas kepada siswa untuk menganalisis sebuah tarian di setasiun TV dari daerah mana saja kemudian guru menyuruh siswa untuk menjelaskan bagaimana properti yang digunakan, busana, tata rias, gerak dan sebagainya. Sedangkan untuk penilaian kelompok guru di dalam kelas menampilkan tayangan video tari dari suatu daerah kemudian secara berkelompok guru menugasi masingmasing kelompok untuk menganilisis kemudian hasilnya dipresentasikan di depan kelas. Dari sini guru melakukan penilaian dengan cara melihat keaktifan siswa dalam menyampaikan dan mempertahankan pendapat mereka dari hasil analisis kepada kelompok siswa yang lain. Bisa dikatakan bahwa guru telah menggunakan jenis penilaian secara tertulis dalam bentuk uraian yaitu menuntut kemampuan siswa untuk mengorganisasi dan merumuskan jawaban de- 
ngan kata-kata sendiri (Djamarah, 2000: 219).

Selain dari hasil penilaian yang dilakukan oleh guru secara individu maupun kelompok, guru juga mengadakan evaluasi bagi dirinya sendiri yaitu dengan mereview penyampaian materi kepada siswa sudah menggunakan metode yang benar atau belum, dan melihat tingkat pemahaman siswa berdasarkan penilaian yang telah dilakukan sudah memenuhi atau belum. Sehingga dapat digunakan sebgai acuan pada pembelajaran berikutnya.

Demikian dapat disimpulkan bahwa guru dalam pembelajaran seni tari di SD Malang telah melakukan evaluasi hasil belajar melalui evaluasi formatif dan menggunakan jenis penilaian berupa tes perbuatan dan tes tertulis, serta evaluasi terhadap metode guru dalam penyampaian materi kepada siswa sesuai dengan teori PAKEM.

\section{Peran serta guru siswa dalam pembelajaran seni tari SD Malang}

Dalam rangka melaksanakan pembelajaran yang bermakna untuk mencapai tujuan pembelajaran yang telah ditentukan, maka peran aktif guru dan siswa sangat berpengaruh dalam pelaksanaan pembelajaran seni tari.

Adapun bentuk keaktifan guru dan siswa selama proses pembelajaran seni tari SD di Malang adalah sebagai berikut :

\section{Keaktifan Guru}

Guru memiliki perenan yang sangat besar dalam upaya peningkatan hasil belajar peserta didik di sekolah. Salah satu upaya yang dapat dilakukan oleh seorang guru adalah memilih pendelatan pembelajaran yang memungkinkan peserta didik berpartisipasi secara aktif, sehingga dapat memahami materi yang dipelajari dan menguasai keterampilan yang diperlukan. Disinilah peran guru berfungsi sebagai motivator dan fasilitator bagi siswa selama proses pembelaja- ran seni tari agar tujuan pembelajaran dapat tercapai dengan meksimal.

Dalam hal ini keaktifan guru sangat diperlukan dalam usaha pencapaian tujuan pembelajaran yangb sudah disusun sebelumnya. Berdasarkan hasil observasi, keaktifan guru seni tari SD di Malang bisa dilihat sebagai berikut :

a. Memantau Kegiatan belajar siswa

Peserta didik terlibat secara aktif dan banyak berperan dalam proses pembelajaran, sedangkan guru lebih banyak memberikan arahan, dan bimbingan serta mengatur jalanya proses pembelajaran (Mulyasa, 2006: 193). Kadang seorang siswa atau sekelompok siswa mengalami kesulitan dalam menyelesaikan tugas-tugas yang telah diberikan. Guru perlu tahu dan memberikan jalan keluar agar siswa tersebut tidak tertinggal dengan siswa yang lain. Guru lebih memposisikan diri sebagai fasilitator yang bertuga memberikan kemudahan belajar (to facilitate of learning) kepada peserta didik.

Hasil observasi yang telah dilakukan bahwa keaktifan guru dalam memantau kegiatan hasil belajar siswa dikelas selalu menanyakan kesulitan-kesulitan belajar siswa selama proses pembelajaran berlangsung. Satu per satu guru memperhatikan kinerja siswa dalam mengerjakan tugas masing-masing seta memberikan pengarahan kepada siswa sehingga siswa semangat untuk menyelesaikan tugas tersebut. Pantauan ini dilakukan oleh guru seni tari dengan tujuan dapat memahami gaya belajar masing-masing siswa serta wahana baru bagi guru dalam menangani permasalahanpermasalahan yang beragam dari siswa. Karena pada dasarnya anak memiliki sifat rasa ingin tahu dan berimajinasi yang berbeda (Kusairi, 2006:1). Guru seni tari aktif melakukan pantauan setiap kali pertemuan sehingga perolehan hasil belajar setiap pertemuan bisa dilihat sebagai bahan untuk evaluasi bagi guru seni tari.

Demikian dapat disimpulkan bahwa guru dalam pembelajaran seni tari di SD 
Malang telah melakukan pemantauan terhadap kegiatan belajar siswa sesuai dengan PAKEM yaitu guru selalu aktif dalam melakukan pantauan kepada setiap siswa dalam kegiatan belajar.

b. Memberikan Umpan Balik

Membiarkan siswa dalam mengembangkan diri berdasarkan pengetahuan dan pengalaman yang dimiliki terutam membantu belajar dari kesalahan-kesalahan yang dilakukan, termasuk hal yang diutamakan dalam pembelajaran aktif (Sapari, 2001: 24). Pemberian umpan balik dari guru kepada siswa merupakan salah satu bentuk interaksi dalam belajar. Umpan balik hendaknya lebih mengungkap kekuatan dari pada kelemahan siswa serta cara memberikan umpan balik pun harus santun, agar siswa percaya diri dalam menghadapi tugastugas selanjutnya.

Hasil observasi diketahui bahwa guru seni tari memberikan umpan balik kepada siswa dengan jalan guru mengumpulkan setiap siswa secara berkelompok. Hal ini dilakukan setelah semua kelompok maju mempresentasikan hasil kerjanya di depan kelas kemudian setelah usai siswa disuruh berkumpul untuk mendapatkan pengarahan. Guru mulai memberikan umpan balik dengan cara mengevaluasi setiap kerja kelompok kemudian guru memberitahukan kekurangan-kekurangan yang harus dibenahi oleh masing-masing kelompok, dengan demikian siswa mengetahui letak kesalahannya dan secara otomatis dapat menimbulkan motivasi siswa untuk melakukan perbaikan dipertemuan berikutnya, selain itu dengan umpan balik ini guru juga bisa memperbaiki pembelajaran dipertemuan berikutnya sehingga bu Umi juga bisa memperbaiki penyampaian materinya. Hal ini senada dengan pendapat yang dikemukakan oleh Sediono (2001:15) bahwa guru harus konsisten dalam memeriksa hasil pekerjaan siswa dan memberikan komentar serta catatan kepada siswa. Catatan guru berkaitan dengan pekerjaan siswa lebih bermakna ba- gi pengembangan diri siswa dari pada hanya sekedar angka.

Pemberian umpan balik (feed back) ini dilakukan guru seni tari pada setiap akhir pelajaran sebagai tolok ukur keberhasilan serta mengukur keefektifan pembelajaran yang telah berlangsung dan dapan dijadikan acuan untuk memperbaikinya.

Demikian dapat disimpulkan bahwa guru dalam pelaksanaan pembelaran seni tari SD di Malang telah memberikan umpan balik kepada siswa yang berkenaan dengan teori PAKEM yaitu menciptakan suatu pembelajaran yang efektif sesuai dengan tujuan pembelajaran.

c. Mengajukan pertanyaan yang

Selain mengajukan pertanyaan yang menantang, seharusnya guru mengajikan pertanyaan yang mengundang banyak jawaban siswa (Kusairi, 2006:9). Hal tersebut perlu dilakukan agar siswa memiliki respon yang tinggi terhadap materi apa yang mereka terima.

Demikian dapat disimpulkan bahwa guru dalam melaksanakan pembelajaran seni tari SD di Malang telah aktif dalam memberikan pertanyaan-pertanyaan seputar materi yang diberikan agar siswa juga aktif dalam mengulang materi yang telah diberikan guru melalui pertanyaan. Menurut Tim Widyaiswara bahwa di dalam pembelajaran PAKEM harus dituntut adanya keaktifan guru dan siswa dalam proses pembelajaran.

d. Mempertanyakan gagasan/ide baru siswa

Memberikan pertanyaan yang menantang untuk berfikir, guru juga menanyakan ide atau gaasan yang murni dari pemikiran siswa itu sendiri sebagai langkah awal dalam pembuatan karya baru dalam mengeksplorasi gerak. Hasilnya masing-masing siswa ternyata memiliki ide yang beragam untuk menentukan tema masing-masing, kemudian dengan bantuan guru mereka diberikan pengarahan secara benar dalam 
mengaplikasikan ide mereka dalam bentuk sajian karya tari. Hasil masing-masing siswa ini banyak sekali bermunculan kekreatifan siswa dalam mengembangkan ide mereka. Bu Umi menenyakan ide siswa pada saat pertemuan awal memasuki materi ekspresi dengan tema mengeksplorasi gerak tari nusantara.

\section{e. Bersahabat dan bersifat terbuka}

Akrab, murah senyum, menyapa nama, dan menepuk pundak adalah beberapa teknik untuk menunjukkan bahwa guru bersahabat dengan siswa (Kusairi, 2006: 9). Guru di dalam kelas memiliki peranan penting dalam proses pembelajaran. Sebagai pusat perhatian siswa, guru harus bisa mengondisikan siswa dan tidak membuat siswa merasa tertekan dikelas dan menampilkan sikap bersahabat serta terbuka kepada siswa.

Berdasarkan hasil observasi bahwa guru dikelas pada saat masuk menunjukkan raut wajah yang ramah, kemudian guru memulai proses pembelajaran. Keterbukaan guru terhadap siswa terlihat pada saat siswa bertanya tentang hal yang tidak dimengerti, guru serta merta menyambut pertanyaan siswa dengan ramahnya dan berusaha menjawab pertanyaan dari siswa. Guru berusaha membina hubungan antara guru dan siswa sebagai suatu keluarga yang didalamnya tidak ada tekanan dan paksaan sehingga siswa berani menanyakan apa yang dirasa belum dimengerti.

Demikian antara guru dan siswa memiliki sebuah ikatan yang erat dalam mendukung proses pembelajaran sehingga tujuan pembelajaran bisa tercapai dengan baik. Sebaliknya jika guru duduk di belakang meja dan ragu-ragu untuk berinteraksi dengan siswa akan memberikan kesan kurang bersahabat dan mengambil jarak, umumnya hal ini menyebabkan siswa menjadi takut untuk aktif di kelas. Akan tetapi guru tidak demikian, bu Umi selalu bersifat terbuka kepada semua siswa dan memperhatikan kesulitan yang dialami siswa, sikap terbuka dan apa adanya juga merupakan indikator guru bersahabat.
f. Menghargai dan merespon jawaban siswa

Guru yang baik harus mau menerima dan menghargai semua pendapat siswa sebagai bentuk perhatian guru. Berdasarkan hasil observasi, bu Umi (bukan nama sebenarnya) menampung semua pertanyaan maupun ide maupun pertanyaan siswa, disini guru berperan sebagai pendengar yang baik dari semua masukan-masukan serta jawaban dari siswa. Secara menyeluruh guru menanggapi ide dan jawaban siswa meskipun jawaban yang dilontarkan siswa belum sempurna atau masih jauh dari benar tapi guru tetap memberikan penghargaan berupa ucapan atau acungan jempol. Hal ini dilakukan oleh guru untuk menghargai hasil pemikiran siswa sehingga siswa bisa berkembang karena pendapat serta jawabanya merasa dihargai dan yang paling utama adalah siswa pun akan lebih mau untuk melakukan hal-hal baru sesuai dengan tingkat kekreatifan masing-masing siswa. Respon positif guru akan mengembangkan motivasi tersendiri bagi siswa dan dapat meyakinkan siswa akan kegunaan materi pembelajaran dalam kehidupan nyata peserta didik (Mulyasa, 2006: 197).

Semangat siswa yang telah mendapat tanggapan dari guru, mereka berusaha mengembangkan ide baru mereka dan dengan demikian dapat disimpulkan bahwa menghargai dan merespon jawaban siswa dapat mempengaruhi psikologis siswa dalam pembelajaran seni tari dan hendaknya sebagai guru jangan pernah menganggap siswa sebagai tong kosong yang tidak ada isinya apa-apa. Dan SD di Malang guru seni tari menghargai semua ide atau jawaban siswa.

g. Membantu siswa menyelesaikan tugas

Adakalanya seorang siswa atau sekelompok siswa mengalami kesulitan dalam menyelesaikan tugas-tugas. Dan sebagai seorang guru harus mengetahui dan paham betul serta memberikan jalan keluar agar 
siswa terbantu bebanya dan tidak tertinggal dengan teman yang lain. Guru harus lebih memposisikan diri sebagai fasilitator, yang bertugas memberikan kemudahan belajar (to facilitate of learning) kepada peserta didik.

Masalah yang dihadapi siswa sangat beragam, entah itu masalah individu siswa itu sendiri ataupun masalah siswa dalam kelompok. Hal ini harus selalu mengerjakan setiap tugas yang diberikan oleh guru. Dengan demikian respon yang diberikan siswa terhadap mata pelajaran seni tari ini merupakan respon positif maksudnya siswa maupun mendukung tercapainya tujuan pembelajaran yang diharapkan sehingga guru mampu menilai tingkat keberhasilan pembelajaran.

Maka dari itu dapat disimpulkan bahwa respon siswa terhadap mata pelajaran bidang seni tari sangat tinggi dan positif. Hal ini bisa dilihat dari keaktifan siswa bertanya, perilaku, den ketekunan yang ditunjukkan siswa selama proses pembelajaran berlangsung.

\section{Pembelajaran Efektif}

Menurut Taruna (2002: 3) pembelajaran efektif adalah proses pembelajaran yang harus mencapai tujuanya sehingga memudahkan proses pembelajaran selanjutnya. Menurut Hamidah (2005: 3) pembelajaran yang efektif adalah pembelajaran yang memberikan kesempatan kepada siswa untuk mengembangkan pengetahuan dan menerapkan hal-hal yang dipelajarinya. Agar tercipata pembelajaran yang efektif hal-hal yang harus dilakukan adalah sebagai berikut.

a. Guru memberikan tugas dengan jelas

Guru sebelum memberikan tugas kepada siswa hendaknya memberikan pengarahan lebih lanjut kepada siswa tentang apa yang akan siswa kerjakan, setelah dirasa cukup guru memberikan tugas dengan jelas kepada siswa sehingga siswa memahami betul tugas apa yang akan mereka kerjakan dan kemungkinan salah dalam pengerjaan tugas dapat diminimalkan. Sehingga tugas yang diberikan bisa terselesaikan dengan baik sesuai dengan tujuan guru.

Berdasarkan hasil observasi di lapangan bahwa guru dalam memberikan tugas kepada siswa disampaikan secara rinci dan memberikan contoh serta langkah-langkah pengerjaan kepada siswa sebelum pemberian tugas. Guru memberikan tugas sesuai dengan materi yang diberikan sebagai tolok ukur keberhasilan pembelajaran pada hari itu. Sebelumnya guru memberikan materi secara panjang lebar kepada siswa kemudian guru selalu menanyakan kepada siswa hal mana yang belum jelas dan menampung pertanyaan siswa. Hal ini sesuai dengan hasil observasi dikelas pada materi ekspresi tanggal 19 Nopember 2009. Adapun kutipan dari guru adalah sebagai berikut :

"...dari penyampaian materi yang saya sampaikan tadi, apakah ada pertanyaan atau mana yang belum paham? sebelum saya memberikan tugas kepada kalian..."

Dari sinilah bisa disimpulkan bahwa guru dalam pemberian tugas sudah jelas, tidak seenaknya dan disesuaikan dengan ting kat pemahaman siswa sehingga siswa siswa tahu apa yang dikerjakan dan pastinya hasil yang diperoleh bisa maksimal.

b. Memperhatikan Waktu

Guru sudah mengira-ngira waktu yang dibutuhkan dalam pengerjaan tugas tersebut. Sesuai hasil observasi, guru memberikan waktu kurang lebih 45 menit untuk mengeksplorasi gerak secara berkelompok, dengan adanya pembatasan waktu ini siswa diharapkan dapat menyelesaikan tugas tepat pada waktunya dengan hasil optimal. Selain itu tujuan pembatasan waktu ini digunakan oleh guru untuk melihat daya serap siswa terhadap materi yang telah diajarkan. Siswapun merasa memiliki tanggung jawab untuk menyelesaikan tugas tepat pada waktunya sehingga siswa bersemangat dan sungguh-sungguh dalam menyelesaikan tugas tepat pada waktunya. 
Demikian dapat disimpulkan bahwa guru sangat memperhatikan waktu dalam proses pembelajaran, bahkan guru sangat tepat waktu masuk ke kelas tanpa terlambat dan mengakhiri pelajaran sesuai jam pelajaran berakhir, hal ini tidak ada maksud apa-apa selain melatih kedisiplinan baik bagi guru atau siswa itu sendiri.

c. Memanfaatkan Sumber Belajar dengan Media Belajar yang tepat

Untuk menciptakan pembelajaran yang efektif salah satunya adalah memanfaatkan sumber belajar dengan media belajar yang tepat. Hasil observasi bahwa guru seni tari dalam penggunaan media belajar sudah dilakukan secara optimal. Guru lebih banyak menggunakan media elektronik dalam proses pembelajaran karena disesuaikan dengan materi ekspresi yang lebih menekankan pada aspek gerak sehingga media yang sering digunakan adalah media elektronik. Media elektronik yang menunjang proses pembelajaran seni tari ini adalah tape recorder, VCD player, kaset dan sebagainya yang kesemuanya itu memiliki fungsi terpenting dalam pembelajaran seni tari di materi ekspresi. Pada materi ekspresi ini siswa sudah membawa kaset pita atau kaset $C D$ sebagai musik iringan hasil tarianya. Siswa menggunakan $V C D$ player bagi yang membawa kaset $C D$ dan menggunakan tape recorder bagi siswa yang membawa kaset pita. Oleh guru pun siswa diajak aktif dalam penggunaan media yang ada agar setiap siswa mampu mengoprasikan media elektronik dengan tepat dan benar.

Demikian dapat disimpulkan bahwa guru pada pembelajaran seni tari di SMPN 20 Malang telah menggunakan sumber belajar serta media secara tepat untuk terciptanya pembelajaran yang efektif sesuai dengan ciri-ciri PAKEM.

\section{Reaksi Siswa}

Adanya keantusiasan siswa dalam merespon setiap materi yang diberikan guru serta keaktifan bertanya siswa maka siswa menunjukkan sikap tekun dalam megerja- kan setiap tugas yang diberikan oleh guru. Dengan demikian respon yang diberikan siswa terhadap mata pelajaran seni tari ini merupakan respon positif maksudnya siswa mampun mendukung tercapainya tujuan pembelajaran yang diharapkan sehingga guru mampu menilai tingkat keberhasilan pembelajaran.

Maka dari itu dapat disimpulkan bahwa respon siswa terhadap mata pelajaran bidang seni tari sangat tinggi dan positif. Dan jika dikaitkan dengan penerapan PAKEM sudah sesuai dengan ciri-ciri PAKEM, hal ini bisa dilihat dari keaktifan siswa bertanya, perilaku, den ketekunan yang ditunjukkan siswa selama proses pembelajaran berlangsung.

\section{Hasil pembelajaran seni tari SD di Malang}

Hasil belajar merupakan produk yang dihasilkan dari proses pembelajaran melalui tahapan evaluasi atau penilaian yang dilakukan oleh guru. Menurut Anas evaluasi adalah kegiatan atau proses menilai sesuatu (2001:5). Untuk dapat menentukan nilai dari sesuatu yang sedang dinilai itu, dilakukanlah pengukuran, dan wujud dari pengukuran itu adalah pengujian, dan pengujian inilah yang dalam dunia pendidikan dikenal dengan istilah tes.

Berdasarkan hasil observasi, sebagai hasil pembelajaran seni tari, guru melakukan penilaian yang disesuaikan dengan materi yaitu materi apresiasi dan materi ekspresi yang memiliki indikator yang berbeda pada masing-masing standart kompetensi yang ingin dicapai. Guru dalam materi apresiasi menggunakan penilaian dengan teknik diskusi dan pengamatan gambar yang terbentuk dalam pernyataan lisan dan tertulis. Dan dalam hasil pembelajaran, diperoleh produk belajar berupa pemahaman siswa dari materi yang diberikan.

Dalam materi ekspresi aspek yang dinilai oleh guru adalah keterampilan dan 
kreatifitas dan menggunakan tes praktik dalam memberikan penilaian. Disini produk belajar yang diperoleh adalah penciptaan karya tari sederhana yang telah dibu at siswa secara berkelompok sesuai dengan tema yang telah mereka tentukan. Demikian produk hasil belajar untuk meteri ekspresi untuk masing-masing kelompok berbeda. Berdasarkan hasil wawancara dengan guru seni tari, bahwa penilaian sebagai produk hasil belajar disesuaikan dengan indikator dari setiap kali pertemuan sehingga pencapaian tujuan pembelajaran bisa terlaksana dengan baik, misalnya untuk indikator "memperoleh gerakan baru dari hasil eksplorasi" maka hasil perolehan gerak baru inilah yang dinamakan produk hasil belajar. Demikian seterusnya sehingga masingmasing indikator dapat tercapai seluruhnya dengan baik sehingga akan menghasilkan berbagai macam produk hasil belajar.

\section{Kesimpulan}

Dengan demikian dapat disimpulkan bahwa produk hasil belajar siswa dalam pembelajaran seni tari SD di Malang didasarkan pada masing-masing indikator yang terdapat dalam rencana pelaksanaan pembelajaran dan sudah sesuai dengan prinsip PAKEM.

\section{DAFTAR PUSTAKA}

Aikhoka, Kana Setya. 2009. Manajemen Pembelajaran PAKEM Studi Kasus di SD Islam Surya Buana Malang. Malang: Jurusan Administrasi Pendidikan.

Ali, Muh. 1987. Guru dalam Proses Belajar Mengajar. Bandung: Sinar Baru Algesindo.

Ali, Saukah dkk. 2000. Pedoman Penulisan Karya Ilmiah. Malang: Biro Administrasi Akademik, Perencanaan, dan Sistem Informasi
Ardhana, Wayan. 1986. Dasar-dasar Pendidikan. Malang: Fakultas Ilmu Pendidikan.

Djamarah, Syaiful Bahri. 2000. Guru dan Anak Didik Dalam Interaksi Edukatif. Jakarta : Rineka Cipta.

Hamidah, Siti Cholidah. 2005. Membangun Formula Pembelajaran Sasatra Yang Efektif. Makalah disajikan dalam Seminar Regional Sastra, Madang, 29 September 2005.

Hidajat, Robby. 2008. Seni Tari. Malang: Jurusan Seni \& Desain Fakultas Sastra Universitas Negeri Malang.

Khusinah, Siti. 2007. Penerapan Pembelajaran Akuntansi dengan Pendekatan PAKEM (Pembelajaran, Aktif, Kreatif, Efektif, dan Menyenangkan) untuk Meningkatkan Prestasi Belajar Siswa pada Mata Diklat Akuntansi Siswa Kelas X Akuntansi SMK PGRI 02 Malang. Malang: Jurusan Akuntansi.

Koestantoniah, dkk. 2003. Pengembangan dan penerapan perangkat pembelajaran SAINS model PAKEM (Pembelajaran, Aktif, Kreatif, Efektif, dan Menyenangkan) Melalui permainan interaktif untuk meningkatkan daya nalar siswa SD Kota Semarang. Semarang: FIP.

Kusairi, Sentot (Kusairi@yahoo.com) 8 September 2009. Apa Itu PAKEM, Ada Apa Dengan PAKEM. E-Mail kepada Siti Khusinah (City_sitee@yahoo.com)

Majid, Abdul. 2008. Perencanaan Pembelajaran (Mengembangkan Standar Kompetensi Guru). Bandung: Remaja Rasdakarya. 